\title{
Pembuatan Content Marketing sebagai Strategi Menumbuhkan Brand Awareness bagi Pelaku Usaha di Era Pandemi Covid-19
}

\author{
Dessy Yunita ${ }^{1 *}$, A. Widad ${ }^{1}$, Yuliansyah M. Diah ${ }^{1}$, dan Wita Farla ${ }^{1}$ \\ ${ }^{1}$ Fakultas Ekonomi, Universitas Sriwijaya, Sumatera Selatan Indonesia \\ *Email Korespondensi: dessyyunita@unsri.ac.id
}

Info Artikel: Diterima: 14 Desember 2020; Disetujui: 01 Oktober 2021; Dipublikasi: 03 November 2021

\begin{abstract}
Abstrak: Perubahan paradigma pemasaran di era Pandemi Covid 19 menyebabkan aktivitas yang dilakukan oleh perusahaan juga mengalami perubahan. Banyak perusahaan yang mengalami kemunduran bahkan menutup usaha yang telah ada sebelumnya. Salah satu hal yang dapat dilakukan oleh perusahaan untuk mempertahankan atau mengingatkan kembali merek yang dikelola perusahaan adalah melalui penciptaaan content marketing. Dalam strategi pemasaran, content marketing adalah sebuah pendekatan yang berfokus pada produksi serta distribusi suatu konten yang bernilai dan relevan serta dilakukan secara konsisten guna menarik dan mempertahankan audiens yang ditargetkan. Pengabdian ini bertujuan untuk meningkatkan pemahaman dan pengetahuan tentang content marketing sebagai salah satu strategi pemasaran yang dapat digunakan di era Pandemi Covid 19. Bentuk presentasi dan pelatihan ditujukan kepada Pelaku Usaha untuk mempelajari bagaimana membuat content marketing yang menarik dan inovatif untuk meningkatan brand awareness pembeli.
\end{abstract}

Kata Kunci: Content Marketing; Brand Awareness; Covid-19

\section{Kutipan:}

Yunita, D., Widad, A., Diah, Y.M., Farla, W. (2021). Pembuatan Content Marketing sebagai Strategi Menumbuhkan Brand Awarness bagi Pelaku Usaha di Era Pandemi Covid-19. Sricommerce: Journal of Sriwijaya Community Services, 2(2): 89-96. DOI: https://doi.org/10.29259/jscs.v2i2.38

\section{PENDAHULUAN}

Perkembangan internet memberikan kemudahan berkomunikasi tanpa batas. Secara fisik, kita dapat melakukan komunikasi pada tempat yang berbeda. Internet menciptakan banyak kemudahan bagi pengguna dalam membantu aktivitas kesehariannya. Kemudahan yang didapat tentunya dapat digunakan untuk menciptakan strategi bersaing di era digital ini. Begitu juga pelaku usaha dapat menciptakan sebuah inovasi dalam aktivitas pemasaran yang ditujukan kepada target pasar dengan memanfaatkan internet.

Aktivitas pemasaran dapat memanfaatkan internet untuk membuat sebuah inovasi yang berbeda, salah satunya dengan membuat pemasaran konten (content marketing) sebagai daya tarik bagi pelanggan. Content Marketing adalah kegiatan pemasaran yang melibatkan pembuatan, kurasi, distribusi, dan memperkuat konten yang menarik, relevan dan berguna untuk kelompok yang spesifik, agar menciptakan pembicaraan soal konten (Kotler et al, 2017). Content marketing adalah sebuah pendekatan yang berfokus pada produksi serta distribusi suatu konten yang bernilai dan relevan serta dilakukan secara konsisten guna menarik target audiens serta mempertahankan audiens yang telah ditargetkan sehingga mampu menstimulasi pelanggan untuk melakukan tindakan yang bisa menghasilkan keuntungan (getcraft, 2016). Banyak perusahaan menggunakan content marketing untuk memasarkan produk /jasa usaha mereka kepada konsumen dan calon 
konsumen (Lieb, 2012).Untuk membuat content marketing, pelaku usaha dapat membuat melalui media sosial, website, video, blog, podcast, dan lainnya.

Berdasarkan hasil penelitian GetCraft (2017) menjelaskan bahwa media sosial aktif digunakan oleh $40 \%$ masyarakat Indonesia dengan pembagian 49\% merupakan pengakses Youtube, 48\% merupakan pengakses Facebook, dan 38\% merupakan pengakses Instagram. Diantara media sosial tersebut dapat dijadikan sebagai sarana content marketing, dimana pengguna satu sama lain dapat berbagi konten dengan bermacam jenis format seperti tulisan, video ataupun gambar. Salah satu penelitian yang dilakukan oleh Damayanti E., dkk (2018) membahas tentang konten marketing yang dilakukan melalui Instagram memudahkan untuk mengetahui dan mendapat informasi tentang produk dan konsep dari usaha yang dijalankan. Konsumenpun juga terdorong untuk melakukan pembelian. Konten yang ada di instagram pemilik usaha bersifat mendidik (mengajarkan kepada pelanggan hal-hal yang perlu diketahui tentang produk tersebut), menghibur (menyajikan informasi dengan cara yang menarik), membujuk (membuat pelanggan untuk melakukan pembelian pada produk) serta menyajikan informasi yang disesuaikan dengan kebutuhan tiap pelanggan.

Sebuah content marketing yang baik dapat menumbuhkan kesadaran merek (brand awareness) sebuah produk. Rangkuti (2004) mengatakan bahwa brand awareness merupakan kemampuan seorang pelanggan untuk mengingat suatu merek tertentu atau iklan tertentu secara spontan atau setelah dirangsang dengan kata-kata kunci. Durianto, et al (2004) brand awareness (kesadaran merek) adalah kesanggupan konsumen (atau calon pembeli) dalam mengingat kembali (recognize) atau mengenali (recall) bahwa suatu merek merupakan suatu bagian dari kategori produk tertentu". Content marketing menurut beberapa penelitian berpengaruh terhadap brand awareness secara yang positif (Hendriyanto T., 2021; Waoma G., \& DwiHartono B., 2020; Pertiwi D \& Gusfa H., 2018). Begitu juga penelitian yang dilakukan oleh Irwan F. et.al., (2020) pada Youtube channel mendapati kesadaran merek (brand awareness) ada pada tingkatan brand recall (mengenali merek). Elisa \& Gordini (2014) dalam penelitiannya juga mendapati penggunaan content marketing mendorong perusahaan mencapai tujuan salah satunya adalah seperti kesadaran merek (brand awareness).

Pembuatan content marketing dianggap salah satu hal penting diera Pandemi Covid 19 ini. Berdasarkan survey yang dilakukan oleh Lyfe Marketing mengatakan bahwa 78\% customer mengetahui sebuah bisnis melalui artikel dibandingkan iklan. Selain itu, 70\% customer lebih percaya dengan sebuah bisnis yang menyediakan berbagai jenis konten. Penciptaan ide kreativitas akan menciptakan konten yang berkualitas. Minimnya kualitas konten dapat menyebabkan tujuan pemasaran menjadi lemah karena tidak memberikan dampak yang maksimal. Pembuatan konten tentunya diawali dengan ide yang disesuaikan dengan tujuan pemasaran. Dengan dibantu teknologi akan memudahkan para pelaku bisnis untuk dapat menjalankan aktivitas pemasaran agar dapat dimengerti oleh konsumen. Perusahaan harus membuat content marketing sebagai aktivitas yang diarahkan untuk memenuhi kebutuhan konsumen akan informasi dan edukasi terhadap produk yang dimiliki oleh perusahaan.

Landasan dan pondasi yang sesuai berdasarkan hasil riset perusahaan dapat membuat content marketing yang baik. Berdasarkan data yang dimiliki pelaku bisnis dapat merancang secara cermat content marketing yang tepat. Pembuatan content marketing ini diharapkan memberikan manfaat yang konsisten dengan memperhatikan waktu dan media yang tepat sehingga bisa menjangkau target pasar yang diinginkan. Pelaku usaha dapat memanfaatkan berbagai media, untuk menjangkau target pasar yang diinginkan. Ada banyak media yang bisa dimanfaatkan seperti: melalui blog, website, media jejaring sosial, dsb (lisnawati et.al., 2021).

Indonesia dan dunia sekarang menghadapi banyak sekali perubahan karena adanya Pandemi Covid 19. Berbagai sektor mengalami banyak kemunduran. Banyak perusahaan yang gulung tikar dan memberhentikan operasionalnya serta berdampak pada pengurangan karyawan. Tidak hanya sektor perusahaan kecil yang berimbas tetapi perusahaan besar pun terkena dampak ini. Banyak hal berubah, mulai dari turunnya pendapatan karena imbas dari perekonomian yang menurun sampai banyak orang dirumahkan. Begitu juga sektor-sektor pemerintahan ataupun swasta mengalami penurunan pada aktivitas perusahaan. 
Selama pandemi ini belum berakhir, otomatis individu maupun pelaku usaha dihadapkan pada kenyataan bahwa kita harus mampu hidup berdampingan dengan pandemi ini. Pelaku usaha harus bangkit dan menata kembali usaha yang telah dimiliki. Usaha harus di gairahkan kembali untuk menunjang sektor ekonomi kembali bangkit dan masyarakat pun bisa mendapatkan pekerjaan dan penghasilan yang layak kembali. Banyak perusahaan yang harus membangkitkan kembali pola pemasaran yang ada dan bahkan mungkin berbeda karena menyesuaikan dengan keadaan sekarang. Oleh karena itu pembuatan content marketing sangat membantu perusahaan untuk dapat membangkitkan kembali keyakinan konsumen terhadap perusahaan dengan menumbuhkan kembali kesadaran akan merek perusahaan (Mavilinda Et.al., 2021).

Banyak perusahaan berusahaan untuk menumbuhkan kembali brand awareness produk mereka. Perubahan yang terjadi menuntut perusahaan harus menyesuaikan dengan new normal diera Pandemi Covid 19. Mengatur ulang strategi pemasaran tentunya harus dilakukan dikarenakan keadaan yang berbeda. Untuk itulah dibutuhkan pemahaman bagaimana bisa membuat content marketing yang sesuai dengan era sekarang dan menumbuhkan kembali akan keberadaan merek sebuah produk. Brand yang memberikan content marketing yang baik akan dapat diingat oleh konsumen secara lebih baik dibandingkan merek-merek lainnya dan mempunyai nilai pembeda dengan pesaingnya. Untuk itu pengabdian ini akan mengambil judul "Pembuatan Content Marketing Sebagai Strategi Menumbuhkan Brand Awareness Bagi Pelaku Usaha Di Era Pandemi Covid 19".

\section{STUDI PUSTAKA}

\subsection{Pengertian Content Marketing}

Content marketing adalah sebuah proses pemasaran dari kegiatan bisnis guna memproduksi dan mendistribusikan suatu konten yang bernilai dan relevan agar menarik, memperoleh, dan melibatkan target konsumen. Content marketing merupakan sebuah strategi pemasaran dimana perusahaan merencanakan, memproduksi serta mendistribusikan konten yang sesuai dengan produk yang dipasarkan perusahaan kepada calon potential customer sehingga mampu mendorong mereka menjadi customer. Dilansir dari Forbes, content marketing merupakan sebuah strategi pemasaran dalam memproduksi dan mendistribusikan sebuah konten yang berharga dan relevan serta dilakukan secara konsisten agar menarik perhatian para calon pelanggan yang ditargetkan. Menurut Neil Patel, content marketing dapat menciptakan suatu relasi yang kuat dengan para pelanggan dalam jangka waktu lama. Oleh karenanya, konten yang diproduksi harus selalu relevan agar tercipta perasaan butuh dalam diri pelanggan yang akhirnya memiliki kedekatan emosional terhadap konten tersebut (dcloudhost, 2020).

\subsection{Manfaat Content Marketing}

Pembuatan contet marketing memiliki banyak manfaat. Strategi ini tentunya dapat digunakan sebagai alat untuk menggaet konsumen lebih banyak dengan memanfaatkan media yang tepat. Daya tarik suatu content marketing dapat dilihat dari konsep yang dibangun oleh content marketing itu sendiri. Adapun manfaat dari penciptaan content marketing:

1. Membangun Brand Awareness; bentuk konsistensi dalam publikasi content marketing yang dilakukan, keunikan, pemilihan media yang tepat dapat membangun kesadaran konsumen terhadap merek pelaku usaha. Peluang baru akan muncul bila kita dapat memanfaatkan strategi ini sebagai salah satu cara dalam memperkenalkan atau mengingatkan kembali produk kita ke masyarakat.

2. Meningkatkan Traffic Pengunjung; penawaran yang terdapat pada content marketing yang ditawarkan bisa sebagai solusi bagi konsumen ketika membutuhkan sebuat produk/ jasa. Konsumen akan tertarik bila content yang dibuat dapat menyajikan kebutuhan ataupun kepentingan seperti yang mereka cari.

3. Meningkatkan Penjualan

4. Meningkatkan Engagement; content yang menarik akan meningkatkan keterikatan konsumen dengan produk anda. 


\subsection{Fungsi Content Marketing}

Penerapan content marketing memiliki fungsi dalam membangun dan mempertahankan identitas merek produk. Berikut dapat dilihat fungsi content marketing lainnya:

1. Memiliki keungulan secara kompetitif di banding perusahaan yang tidak memiliki content pemasaran.

2. Terjalinnya hubungan jangka Panjang dan terpercaya dengan konsumen.

Adapun kemampuan yang dibutuhkan dalam content marketing sebagai berikut:

1. Menulis

Telaah gaya mana yang dirasa sesuai dengan produk yang Anda jual dengan cara melakukan riset dari berbagai sumber sehingga akan meningkatkan keahlian dalam membuat tulisan. Dengan melakukan riset juga dapat memperoleh ide dan karya yang dibutuhkan dalam membuat tulisan.

2. Mengembangkan Cerita

Salah satu bentuk konten dalam content marketing adalah membuat video. Keterampilan dan bakat dalam bidang ini bisa dikembangkan dengan mengikuti kelas public speaking, mendengarkan banyak radio, menonton video, atau sumber lainnya.

3. Komunikasi

Skill komunikasi baik verbal maupun non verbal harus terus diasah karena dalam content marketing dituntut harus memiliki skill komunikasi yang baik terutama dalam proses produksi dan distribusi konten sehingga makna yang ingin disampaikan dari konten tersebut mudah diketahui dan dipahami oleh target penonton.

Menurut (Yusuf et.al., 2020) terdapat beberapa faktor untuk membuat content marketing menjadi menarik dan kreatif, yaitu:

1. Design

Sebuah konten yang baik dan menarik tidak akan memiliki pengaruh yang besar apabila tidak diseimbangkan dengan desain yang menarik juga. Penempatan tata letak tipografi akan menimbulkan perhatian dari khalayak. Pemilihan desain background, pemilihan warna dan tata letak (layout) yang baik menimbulkan respons psikologis.

2. Current Event

Konten yang baik menyajikan berita kejadian dan fenomena terkini, sehingga konten akan dapat terbaca olhe Google dan mengunjungi situs ataupun media sosial yang dipakai.

3. The Reading Experience

Desain yang menarik tidak hanya sekedar warna-warna dan gambar yang menarik perhatian, tetapi juga bagaimana tata letak dan penggunaan font tetap terbaca dengan baik dan effortless.

4. Timing

Setelah membuat konten dengan menarik melalui desain dan mudah dibaca, selanjutnya adalah kapan dan berapa banyak konten tersebut diunggah. Intensitas dan frekuensi yang konsisten akan menimbulkan dampak tersendiri.

5. Tone

Kesesuaian berita akan mempengaruhi pada keputusan pembelian pelanggan.

\subsection{Brand Awareness}

A brand is a name, term, sign, symbol or design or combination of them, intended to identify the goods or service of one seller of group of sellers and differentiate them form those of competitors (Kotler \& Amstrong, 1997). Kemampuan seorang calon pembeli dalam mengenali atau mengingat kembali bahwa suatu merek merupakan bagian dari kategori produk tertentu disebut dengan kesadaran merek (Brand Awareness). Brand awareness adalah kekuatan eksistensi suatu merek dibenak konsumen (Ambadar, 2007). Brand awareness meliputi brand recognition yaitu pengenalan merek yang diketahui oleh customer, brand recall (merek apa saja yang pernah dingat oleh customer 
dalam suatu kategori), top of mind yaitu merek yang pertama kali terlintas dibenak customer atas satu produk tertentu dan dominant brand yaitu merek yang hanya satu-satunya tertanam di benak customer. Tingkat kesadaran yang dicapai dipengaruhi dari peran kesadaran merek dalam keseluruhan ekuitas merek. Adapun tingkatan dari kesadaran merek, sebagai berikut:

1. Unaware of brand: pada tingkat ini konsumen sama sekali tidak menyadari adanya suatu merek. Ini adalah tingkat yang paling bawah dalam piramida kesadaran merek.

2. Brand recognition (pengenalan merek): saat akan melakukan pembelian, pembeli akan mengenali suatu merek dari suatu produk tertentu sebelum akhirnya memutuskan untuk membeli dari suatu merek. Ini adalah tingkat yang minimal dalam pyramid kesadaran merek.

3. Brand recall (pengingatan kembali terhadap merek), dengan cara menanyakan sesorang untuk menyebutkan merek tertentu atas suatu kategori produk tertentu di dalam benak konsumen tanpa adanya bantuan.

4. Top of mind (puncak pikiran), yaitu suatu merek yang paling pertama kali terlintas di benak konsumen atau pertama kali disebutkan oleh konsumen. Hal ini berarti merek yang disebutkan tersebut merupakan merek utama dari suatu kategori produk tertentu (Kertamurti, M., 2019).

\section{METODE}

\subsection{Khalayak Sasaran}

Pada kegiatan pengabdian masyarakat ini ditujukan bagi pemilik usaha yang ada di Kecamatan Ilir Barat II sebanyak 25 orang yang memiliki berbagai macam bisnis.

\subsection{Metode Pelaksanaan Kegiatan Pengabdian}

Pelaksanaan kegiatan Pengabdian Pada Masyarakat ini dilaksanakan dengan menggunakan metode pembagian materi serta berdiskusi. Adapun sistematika pelaksanaan kegiatan pengabdian ini adalah sebagai berikut:

1. Langkah 1 (Metode Pembagian Materi)

Peserta diberikan pengetahuan dan pemahaman mengenai content marketing dan brand awareness.

2. Langkah 2 (Metode Tutorial)

Peserta diberikan materi mengenai strategi pemasaran digital dan mempraktikan beberapa strategi pemasaran digital yang telah diberikan.

3. Langkah 3 (Metode Diskusi)

Peserta pelatihan diberikan kesempatan untuk mendiskusikan permasalahan yang dihadapi selama masa pandemi COVID-19 termasuk hal-hal yang berkaitan dengan strategi pemasaran digital.

4. Langkah 4 (Evaluasi)

Peserta pelatihan diberikan lembar kuisioner evaluasi untuk memberikan penilaian terhadap penyelenggaraan kegiatan pengabdian masyarakat mengenai pembuatan content marketing sebagai strategi menumbuhkan brand awareness bagi pelaku usaha di era pandemi COVID19 bagi pelaku UMKM di kota Palembang.

\subsection{Waktu dan Rencana Jadwal Kegiatan}

Pelaksanaan kegiatan pengabdian kepada masyarakat ini mulai dilaksanakan dari tahapan penyusunan proposal pengabdian sampai kesiapan untuk seminar selama 5 (lima) bulan, yaitu bulan Agustus - Desember 2020. Kegiatan penyuluhan ini melibatkan narasumber yang berasal dari Lembaga Pertelevisian. 
Tabel 1 Waktu dan Rencana Jadwal Kegiatan

\begin{tabular}{|c|c|c|c|c|c|c|c|c|c|c|c|c|c|c|c|c|c|c|c|c|c|}
\hline \multirow{2}{*}{ No } & \multirow{2}{*}{ Kegiatan } & \multicolumn{4}{|c|}{ Agustus } & \multicolumn{4}{|c|}{ September } & \multicolumn{4}{|c|}{ Oktober } & \multicolumn{4}{|c|}{ November } & \multicolumn{4}{|c|}{ Desember } \\
\hline & & 1 & II & III & IV & 1 & II & III & IV & 1 & II & III & IV & $\mathbf{I}$ & II & III & IV & 1 & II & III & IV \\
\hline 1 & $\begin{array}{l}\text { Penyusunan } \\
\text { Proposal }\end{array}$ & & & & & & & & & & & & & & & & & & & & \\
\hline 2 & $\begin{array}{l}\text { Persiapan Materi } \\
\text { Pelatihan }\end{array}$ & & & & & & & & & & & & & & & & & & & & \\
\hline 3 & $\begin{array}{l}\text { Pelaksanaan } \\
\text { Pelatihan }\end{array}$ & & & & & & & & & & & & & & & & & & & & \\
\hline 4 & $\begin{array}{l}\text { Pembuatan } \\
\text { Laporan }\end{array}$ & & & & & & & & & & & & & & & & & & & & \\
\hline 5 & Seminar Hasil & & & & & & & & & & & & & & & & & & & & \\
\hline
\end{tabular}

\section{HASIL DAN PEMBAHASAN}

\subsection{Deskripsi Kegiatan}

Kegiatan Pengabdian Pada Masyarakat ini dilaksanakan di Kecamatan Ilir Barat II dengan jumlah peserta 25 orang yang berasal dari pelaku bisnis di daerah setempat. Peserta tersebar dari berbagai jenis usia dan didominasi oleh kaum ibu-ibu.

\subsection{Tahapan Kegiatan}

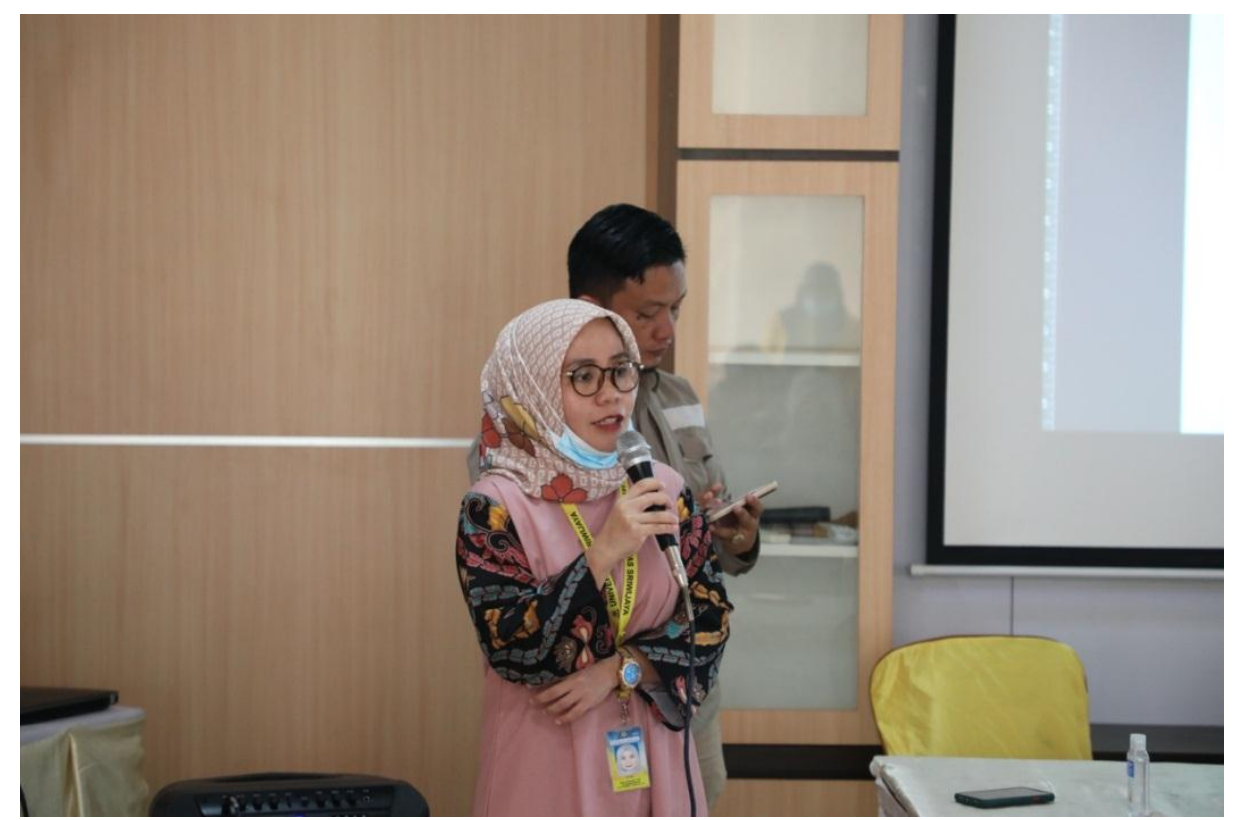

Gambar 1. Pembukaan oleh Dessy Yunita Sebagai Ketua Pelaksana

Tahapan kegiatan dimulai dari Pemberian Materi yang disampaikan oleh Praktisi Pertelevisian dari Sriwijaya TV yaitu Bapak Romi Adriansyah Sastra sebagai Produser, Pengarah Produksi, Maneger News \& Program PT. Palembang Sriwijaya Televisi. Sebagai pakar pertelevisian pak Romi menjelaskan secara detail dan jelas terkait pembuatan Content Marketing bagi pelaku usaha. Pelaku usaha dibuka wawasan mengenai tahapan pembuatan content marketing yang memiliki nilai jual dengan memanfaatkan berbagai media. 


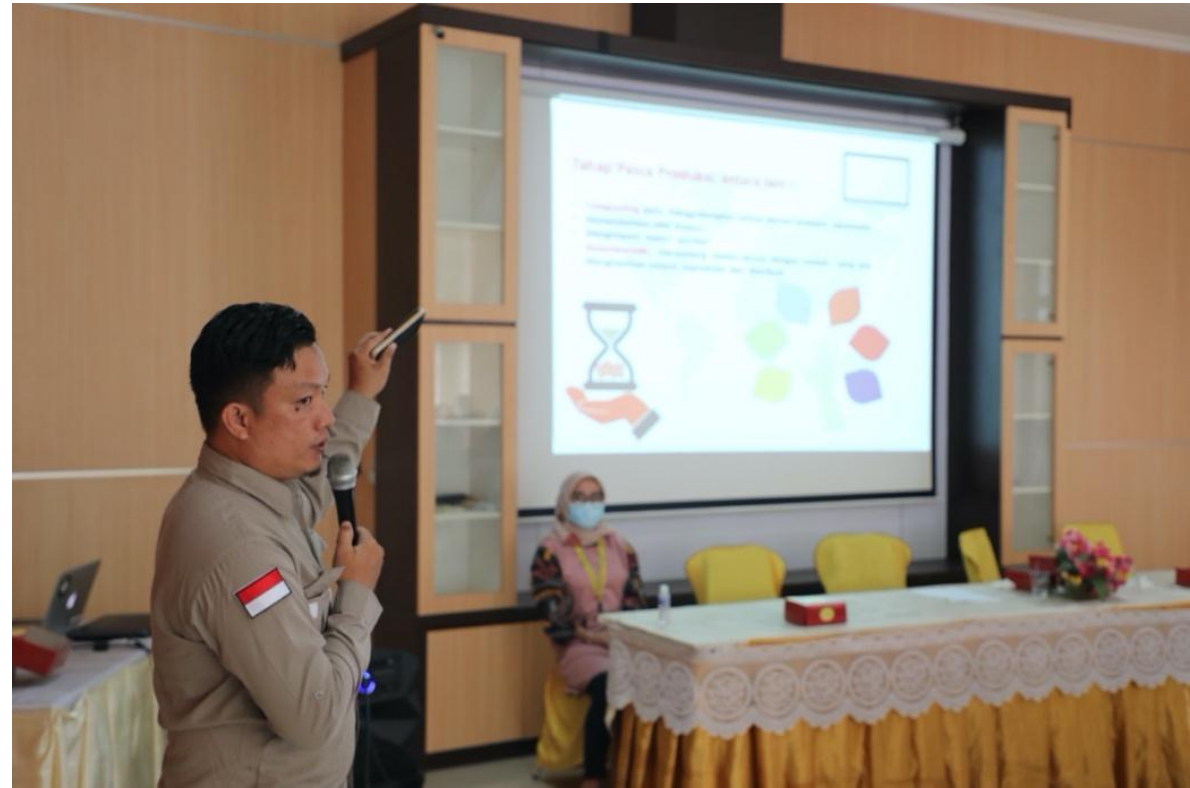

Gambar 2. Penyuluhan oleh Nara Sumber Kepada Peserta UMKM

Peserta merasa antusias mendengarkan penjelasan secara langsung dari praktisi pertelevisian yang memiliki pengalaman dan kemampuan dalam pembuatan content marketing. Penjelasan tahap pelatihan bisa dilihat dari materi yang disampaikan sebagai berikut:

1. Menjelaskan pentingkan konten sebagai sarana promosi usaha.

2. Video merupakan media yang dinamis dan interaktif dalam membuat content marketing.

3. Menjelaskan cara membuat content marketing; dimulai dari penciptaan ide, melakukan riset, menyiapakan story board, melakukan shooting, logging, editing, writing dan mixing.

4. Menjelaskan tahap pra produksi

5. Menjelaskan tahap produksi.

6. Menjelaskan tahap pasca produksi.

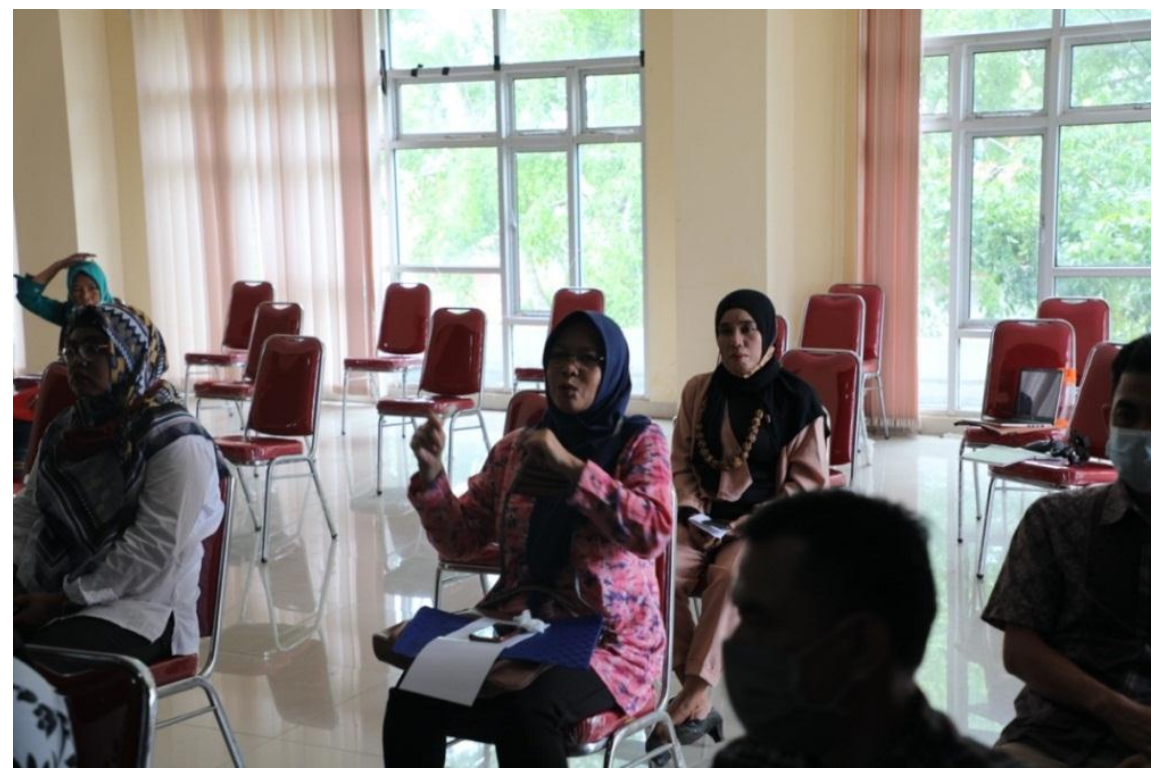

Gambar 3. Tanya Jawab Narasumber Bersama Peserta UMKM

Setelah materi disampaikan, maka peserta diberikan bentuk evaluasi berupa kuesioner dipenghujung acara. Hal ini dilakukan sebagai bentuk umpan balik dari pelatihan yang diberikan kepada pelaku usaha. 


\section{SIMPULAN}

Content marketing bisa digunakan bagi jenis usaha apapun, baik perusahaan kecil ataupun besar maupun yang sedang berkembang. Dengan menggunakan media yang tepat maka pelaku usaha dapat menyasar pada target pasar yang sesuai. Untuk itu dengan pengembangan content marketing yang menarik dapat membantu pelaku usaha memasarkan produknya secara tepat dengan menggunakan strategi kreatif. Pengembangan melakui ide-ide yang cemerlang akan bisa membuat content marketing pelaku usaha menjadi menarik. Pelaku usaha diharapkan bisa melaksanakan bentuk pelatihan ini menjadi satu bentuk pembuatan content marketing yang menarik tentunya dengan ide-ide yang berbeda sehingga dapat dijadikan "pembeda" dengan produk lainnya.

\section{UCAPAN TERIMA KASIH (ACKNOWLEDGMENTS)}

Kami mengucapkan terima kasih banyak kepada Fakultas Ekonomi Universitas Sriwijaya atas dana Pengabdian Kepada Masyarakat yang telah dianggarkan, dan kepada seluruh peserta UMKM Kerajinan Songket dari Daerah Tangga Buntung Palembang Sumatera Selatan.

\section{REFERENSI}

Ambadar, J. (2007). Mengelola Merek. Jakarta: Yayasan Bina Karsa Mandiri.

Damayanti, E., \& Pamungkas, I. N. A. (2018). Konten Digital Marketing Melalui Instagram Warteg Hipster Sebagai Upaya Membangun Brand Awareness. eProceedings of Management, 5(1), 1333-1340.

Durianto, D. (2004). Strategi Menaklukkan Pasar Melalui Riset Ekuitas dan Perilaku Merek. Jakarta: PT Gramedia Pustaka Utama.

Elisa, R. \& Gordini, N. (2014). Content Marketing Metrics: Theoretical Aspects And Empirical Evidence. European Scientific Journal, 10 (34), 92-104.

Hendriyanto, S. T. (2021). Pengaruh Content Marketing Terhadap Brand Awareness Dalam Membangun Customer Engagement Pada Instagram Shopee (Studi Kasus Pada Mahasiswa Universitas Pertamina). Repository Pertamina University.

lisnawati, I., Rosa, A., \& Yunita, D. (2021). Penerapan Strategi Harga Digital (E-Price) dan E-Wallet pada Usaha dengan Platform Digital. Sricommerce: Journal of Sriwijaya Community Services, 2(1), 53-58. doi:https://doi.org/10.29259/jscs.v2i1.39.

Irwan, F., Tjahjo, J. D. W., \& Goenawan, F. (2020). Brand Awareness Produk kecantikan Nacific Melalui YouTube Channel Korea Reomit. Jurnal e-Komunikasi, 8(2), 1-7.

Kertamurti, R. (2019). Strategi Kreatif dalam Periklanan. Jakarta: PT. RajaGrafindo Persada. Kotler, P. \& Amstrong, G, (1997). Dasar-dasar Pemasaran. Jakarta: Prehanlindo.

Kotler, P., Kartajaya, H., \& Setiawan, I. (2017). Marketing 4.0: Moving from Traditional to Digital. New Jersey: John Wiley \& Sons.

Lieb, R. (2012). Content Marketing: Think Like a Publisher - How to Use Content to Market Online and in Social Media. USA: Que Publishing.

Mavilinda, H., Nazaruddin, A., Nofiawaty, N., Siregar, L., Andriana, I., \& Thamrin, K. (2021). Menjadi "UMKM Unggul" Melalui Optimalisasi Strategi Pemasaran Digital dalam Menghadapi Tantangan Bisnis di Era New Normal. Sricommerce: Journal of Sriwijaya Community Services, 2(1), 17-28. doi:https://doi.org/10.29259/jscs.v2i1.29.

Pertiwi D. \& Gusfa H. (2018). Pengaruh Content Marketing Terhadap Pembentukan Brand Awareness Pada Kalbis Institute, Jurnal Media Kom, 8(2), 45-57.

Rangkuti, F. (2004)., The Power of Brand. Jakarta: PT Gramedia Pustaka Utama.

Waoma, G., \& Hartono, B. D. (2020). Brand Awareness Properti : Analisis Content Marketing Dan Social Media ( Kasus : Citra Garden City Jakarta) . Jurnal Manajemen Bisnis Dan Publik (JMBP), 1(2), 41-47. https://doi.org/10.22236/jmbp.v1i1.5698.

Yusuf, R., Hendrayati, H., \& Adi Wibowo, L. (2020). Pengaruh Konten Pemasaran Shopee Terhadap Keputusan Pembelian Pelanggan. Jurnal Manajemen Pendidikan dan IImu Sosial, 1(2), 506515. https://doi.org/10.38035/jmpis.v1i2.289. 